\title{
Література:
}

1. Дистрибутивний аналіз. URL: https://uk.wikipedia.org/wiki

2. Кочерган М. П. Загальне мовознавство: підручник. К., 2006. 464 с.

3. Селіванова О. О. Сучасна лінгвістика: напрями та проблеми: підручник. Полтава, 2008. 712 с.

DOI https://doi.org/10.30525/978-9934-26-073-5-2-12

\section{ЖАРГОННІ ФРАЗЕОЛОГІЗМИ ЯК ОСОБЛИВА СКЛАДОВА МІСЬКОГО МОВЛЕННЯ}

\author{
Гарлицька Т. C. \\ кандидат філологічних наук, \\ доцент кафедри англійської мови з методикою викладання \\ Криворізького державного педагогічного університету \\ м. Кривий Ріг, Дніпропетровська область, Украӥна
}

Вивчення мови сучасного міста $\epsilon$ одним із найактуальніших питань соціолінгвістики, основним завданням якої $є$ «чітка скерованість на соціальну природу мови, іiї комунікативну функцію, відношення мови й суспільства, поведінки соціально заангажованого індивіда» [1, с. 71]. Тому під час дослідження міського мовлення важливо враховувати усі суспільно-політичні, економічні, соціальні, культурні зрушення, які відбуваються сьогодні в окремій країні та у світі в цілому. Одними з таких змін $\epsilon$ розкутість сучасного суспільства, демократизація ЗМІ та художньої літератури, прагнення містян підвищити свій соціальний статус, різні види соціальних потрясінь, які стали причиною активного творення та функціонування нелітературних одиниць не лише в усному, але й у писемному мовленні.

До нелітературних / субстандартних елементів, які функціонують у мовленні міста, ми зараховуємо лексичні та фразеологічні одиниці проміжних / периферійних типів (просторіччя, койне, суржик, піджин, креол, інтердіалект) та різні види соціальних діалектів (сленг, професійний та корпоративний жаргон, арго). Питанням збагачення та функціонування некодифікованих фразеологічних елементів присвячено низку праць зарубіжних та вітчизняних мовознавців (Е. Партридж, Г. Менкен， В.Флейшер，А.Бахі， Р. Менон， М. Маковський， О. Сербенська, О. Стишов, О. Тараненко, Н. Третяк). Задля виявлення типових рис жаргонних фразеологізмів, які функціонують у мовленні будь-якого 
сучасного міста, ми розглядаємо їх на матеріалі української, російської та англійської мов.

Характерною особливістю жаргонних фразеологізмів $є$ те, що вони поєднують в собі риси фразеологізмів і сленгу, а саме: вони є семантично пов'язаними сполученнями слів, що відтворюються у вигляді усталеної, неподільної, цілісної конструкції; вони творяться в середовищі живої розмовної мови; належать до шару нелітературної фразеології; носять яскраво виражений емоційно-експресивний оцінний характер та характеризують мовлення широких прошарків молоді, часто, як вияв солідарності за віком та групової ідентифікації [6, с. 310]. Тому, як сленг, жаргонні фразеологізми можна поділити на загальні та спеціальні; як фразеологізми, їх поділяють на субстантивні (іменникові), ад’єктивні (прикметникові) і дієслівні.

До загальних ми зараховуємо той шар сучасних сленгових фразеологізмів, який не $\epsilon$ належністю окремих соціальних груп, і який однаково використовують (чи розуміють) усі жителі міста. Такі фразеологічні жаргонізми є досить частотними у трьох досліджуваних мовах, що пояснюється прагненням міських жителів надати висловлюванню емоційно-експресивного забарвлення та створити гумористичний ефект. Наприклад: на банщі - у стані алкогольного сп'яніння, дерти лаха - сміятися, твій номер шостий - не втручайся у справи інших [5] в укр. мові; жара и немщы - вираження будь-якої сильної емоції, ни петь, ни рисовать (свистеть) - не розуміти чогось, уйти в загс сховатися [4] - у рос. мові; apples and oranges - дві непоєднувані речі, can of worms - складна ситуація [3] - в англ. мові.

Спеціальні жаргонні фразеологізми поділяються на корпоративні та професійні. Корпоративні - це соціально зумовлений різновид фразеологічних жаргонізмів, заснований на виокремленні людей за соціальними ознаками, віком, тобто за видами, не пов'язаними 3 професійною діяльністю (наприклад, молодіжний, кримінальний, шкільний сленги). Найчисленнішими та найяскравішими серед них $\epsilon$ молодіжні жаргонні фразеологізми, функціональним призначенням яких $є$ прагнення молоді надати мовленню більшої емоційності, цікавості, привабливості, «виділитися» серед своїх, похизуватися умінням слідувати новим мовним тенденціям. Наприклад: викочувати шари - дивуватися, дай n'ять - все добре, мізки компостувати - говорити не по суті [5] - в укр. мові; косяки пороть - зробити помилку, мочить корки - шуткувати [4] - у рос. мові; ball-and-chain - тягар, no-no - заборонений [3] - в англ. мові.

До професійного жаргону, за словами Б. Ларіна, належать стійкі словосполучення, які відбивають то давні прийоми роботи, то спеціальні 
форми спілкування учасників колективної праці, то погляди ремісників або промисловиків на свою працю [2, с. 36]. Вони теж є надзвичайно яскравими та використовуються задля впливу на співрозмовника. Наприклад: гріти лавку - перебувати на лавці штрафників [5]; закатать банку - забити гол [4]; tickle the ivories - про погану гру на піаніно [3].

Якщо розглядати жаргонні фразеологізми за морфологічними ознаками, то найчастотнішими серед них $є$ іменникові та дієслівні. Перевага таких стійких зворотів «полягає в тому, що вони в невеликому об'ємі насичені раціональним і емоційним змістом, тобто відбувається, так звана, економія мовних засобів» [7, с. 51]. Наприклад: без иуму $i$ пилу без зайвої уваги і доказів скоєного, бобик здох - про стан втоми, виснаження, глист у корсеті - дуже худий чоловік [5]; ни петь, ни рисовать (свистеть) - не розуміти чогось, держи карман иире - відмова платити [4]; to walk on sunshine - бути дуже задоволеним, щасливим, to have legs - мати здібність підтримувати свою популярність [3].

Ще однією особливістю жаргонних фразеологізмів є їх здатність віддзеркалювати культурно обумовлене ставлення представників певної нації до історичних подій та явищ, які відбуваються в житті сучасного містянина.

Отже, жаргонні фразеологізми є надзвичайно важливим та яскравим компонентом структури мови міста. Поєднуючи в собі ознаки фразеологізмів та сленгу, вони відображають соціально-культурні, історичні, мовні особливості міських жителів та передають їх емоційно-експресивне ставлення один до одного і до навколишньої дійсності.

\section{Література:}

1. Башманівський О. Фразеологічні одиниці вживані підлітками в контекстів соціальної диференціації мовних одиниць американського варіанту англійської мови. Теоретична $i$ дидактична філологія. 2012. Вип. 13. С. 71-74.

2. Ларін Б. Про народну фразеологію. Украӥнська мова в школі. 1959. № 5. С. 29-36.

3. Маковский М. Краткий словарь английских социальных диалектов. Английские сочииальные диалекты (онтология, структура, этимомлогия): учеб. пособие. Москва, 1982. С. 75-131.

4. Словарь современного русского города: Ок. 11000 слов, ок. 1000 идиоматических выражений / под. ред. Б. И. Осипова. Москва, 2003. $565 \mathrm{c}$. 
5. Ставицька Л. Короткий словник жаргонної лексики української мови : Містить понад 3200 слів і 650 стійких словосполучень. Київ: Критика, 2003. 336 с.

6. Толстова О. Мотиваційні моделі фразеології іспанського молодіжного сленгу. Проблеми семантики, прагматики та когнітивної лінгвістики. 2012. Вип. 22. С. 308-315.

7. Шинкаренко I. Ненормативна лексика у молодіжному мовленні як відображення психологічних та соціальних конструктивів. Метафора та ї̈ семіотичний контекст: матеріали наук.-практ. семінару (Дніпро, 17 березня 2017 р.). Дніпро : ДДУВС, 2017. С. 48-52.

DOI https://doi.org/10.30525/978-9934-26-073-5-2-13

\title{
ДЕНОТАТИВНА ПРИРОДА ЗІСТАВЛЕННЯ УКРАЇНСЬКИХ ТА АНГЛІЙСЬКИХ НОМІНАЦІЙ ВІДПОВІДНИХ ПОНЯТЬ
}

\author{
Іваницька Н. Л. \\ доктор філологічних наук, професор, \\ професор кафедри украӥнської мови \\ Вінницького державного педагогічного університету \\ імені Михайла Кочюбинського \\ Родюк Н. Ю. \\ кандидат філологічних наук, доцент, \\ завідувач кафедри української мови \\ Вінницького державного педагогічного університету \\ імені Михайла Коияюбинського \\ Хіміч Г. I. \\ магістрантка кафедри украӥнської мови \\ Вінницького державного педагогічного університету \\ імені Михайла Кочюбинського \\ м. Вінниця, Україна
}

«Денотат», «мікроденотат», «денотативний аспект», «денотативна ситуація», «денотативний принцип», «денотативна сема» - ці, як i подібні терміни закріпилися в лінгвістиці. Узвичаєним став термінообсяг багатьох інших термінів, які об’єднує денотативний принцип (підхід) до 